\title{
The Feasibility Research of Organizing Dragon-and- lion Dance in the Ordinary Universities of Wuhan
}

\author{
Dunfeng Zhou \\ DongfengRoad No.816, Wuhan, Hubei, China
}

\begin{abstract}
By adopting the literature review, expert interview and logical analysis, this paper has made a detailed analysis and research into the feasibility of organizing dragonand-lion dance in the ordinary universities of Wuhan. The research results show that the organization of dragon-and-lion dance which is a form of traditional Chinese culture with a long history in the universities can improve the physical and mental health of those college students, cultivate their sense of national pride as well as strengthen their awareness of cherishing and inheriting the national cultural heritage. The universities can play an important role in popularizing dragon-and-lion dance, thus achieving the goal of national fitness education and also further facilitating the popularity and development of dragonand-lion dance among the public.
\end{abstract}

Keywords-dragon-and-lion dance; ordinary universities in Wuhan; feasibility

\section{INTRODUCTION}

China is home to dragon-and-lion dance. Since dragon-andlion dance was created, it has been popular among the people of all nationalities. After going through the booming development for many generations, the brilliant culture of dragon-and-lion dance has been formed. Therefore, with the aim of enriching the educational curriculum in the universities and upholding the spirit of traditional sports culture, this project is devoted to researching and surveying the current status of dragon-and-lion dance in the ordinary universities of Wuhan. Besides putting forward some feasible suggestions, this paper has also provided some powerful theoretical basis for the popularity and development of dragon-and-lion dance in the universities of Wuhan.

After conducting the questionnaire aimed at the coaches and industrial experts of dragon-and-lion dance in the ordinary universities of Wuhan, this paper has proposed the factors influencing the dragon-and-lion dance in the ordinary universities of Wuhan and also put forward some countermeasures to make the improvement.

\section{THE BASIC ANALYSIS OF THE CURRENT StATUS OF} DRAGON-AND-LION DANCE IN THE ORDINARY UNIVERSITIES OF WUHAN

Universities have become a cradle of dragon-and-lion dance and thus played a key role in developing dragon-and-lion dance. Wuhan is home to 82 universities and colleges with as many as 1.04 million college students. Although they have favorable conditions for developing dragon-and-lion dance, only 10 universities of them have formed the dragon-and-lion dance teams.
As seen in the Table I, only 49 percent of 30 universities in Wuhan surveyed have owned a dragon-and-lion dance team or have been making preparation to bring dragon-and-lion dance to the campus. It is obvious that the dragon-and-lion dance have not yet gained popularity in the universities of Wuhan. Wuhan has not yet made the best of its rich university human resources and thus failed to achieve the goal of upholding the national traditional culture and developing the dragon-and-lion dance advocated by the cultural and sports bureau in Wuhan.

TABLE I. THE SURVEY OF THE CURRENT STATUS OF DRAGONAND-LION DANCE IN THE UNIVERSITIES OF WUHAN

\begin{tabular}{|c|c|c|c|}
\hline & $\begin{array}{c}\text { Have a dragon- } \\
\text { and-lion dance } \\
\text { team }\end{array}$ & $\begin{array}{c}\text { Being } \\
\text { prepar } \\
\text { ed }\end{array}$ & $\begin{array}{c}\text { Have not yet } \\
\text { taken relevant } \\
\text { action }\end{array}$ \\
\hline Number & 10 & 5 & 15 \\
\hline Percent & 33 & 16 & 50 \\
\hline
\end{tabular}

As seen in the Table II, the dragon-and-lion dance in the universities of Wuhan basically takes the form of professional training team. The dragon-and-lion dance taking the form of student association center and specialized required course is still rare. Among those universities organizing dragon-and-lion dance on campus, Wuhan Sports University is the first one to offer the specialized required course relevant to dragon-andlion dance. After that, some other universities in Wuhan followed its example. Since the dragon-and-lion dance team of Wuhan Sports University was formed in 2002, it has represented Hubei Province and Wuhan Sports University to take part in various competitions both at home and abroad and also won some honors.

TABLE II. THE SURVEY OF THE FORM OF DRAGON-AND-LION DANCE IN THE UNIVERSITIES OF WUHAN

\begin{tabular}{|c|c|c|c|c|}
\hline & $\begin{array}{c}\text { Professioal } \\
\text { training } \\
\text { team }\end{array}$ & $\begin{array}{c}\text { Student } \\
\text { associati } \\
\text { on enter }\end{array}$ & $\begin{array}{c}\text { Specializd } \\
\text { equired } \\
\text { course }\end{array}$ & $\begin{array}{c}\text { Elective } \\
\text { PE } \\
\text { course }\end{array}$ \\
\hline Number & 10 & 6 & 5 & 9 \\
\hline Percent & 33 & 20 & 16.7 & 30 \\
\hline
\end{tabular}

Moreover, the enthusiasm for dragon-and-lion dance has been soaring in some other universities in China. According to relevant surveys aimed at 50 universities, 27 universities of them have offered the PE program. Among the 27 universities, 22 of them have offered the courses related to dragon-and-lion dance, accounting for 81.47 percent of the 27 universities. There are 5 universities making preparation to set up the courses related to dragon-and-lion dance. They have accounted for the remaining 18.53 percent of the 27 universities. As an emerging course for the college students majoring in physical education (PE), dragon-and-lion dance has rapidly developed into an important part of the teaching content for the PE 
program in Chinese universities. Beijing Sport University and Hunan Normal University are the first to offer the courses relevant to dragon-and-lion dance. After that, 52 universities in China, including Shanghai University of Sport, Capital University of Physical Education and Sports, South China Normal University and Zhaoqing University, also established their own association and club for dragon-and-lion dance one after another. The development course of dragon-and-lion dance can be summarized as follows. The period from 2001 to 2003 represents the early stage. From 2003 to 2005, dragonand-lion dance experienced fast development in the universities. In 2001, dragon-and-lion dance entered Beijing Sport University in the form of an emerging discipline. It also becomes a required course for those students in Wushu School for the first time. It means that the course of dragon-and-lion dance in the universities has a bright prospect. Compared with some other universities in China, those ordinary universities in Wuhan have fallen behind in terms of dragon-and-lion dance, which is not consistent with upholding and developing the traditional Culture in Wuhan. Therefore, it is quite important and also necessary to organize dragon-and-lion dance in the ordinary universities of Wuhan.

\section{THE BASIC ANALYSIS OF THE CURRENT STATUS OF TEACHING FACULTY FOR DRAGON-AND-LION DANCE IN THE ORDINARY UNIVERSITIES OF WUHAN}

It is widely advocated that great efforts should be made to uphold the national traditional culture and develop dragon-andlion dance. With the growing influence of dragon-and-lion dance on the society, it has been gaining popularity among the public. Dragon-and-lion dance is a comprehensive sports form which combines competition, skill, performance, art appreciation and entertainment. Accompanied by drum performance, various movements of dragon-and-lion dance can create the happy and eye-catching atmosphere, whether it is for large-scale performance or various competitions. The instruments for dragon-and-lion dance has been also innovated and simplified gradually. With a growing number of universities organizing dragon-and-lion dance, it has motivated more teachers and students to participate in it. As to the teaching faculty for dragon-and-lion dance in the universities of Wuhan, Naval University of Engineering has assigned fulltime teachers and professional judges to dragon-and-lion dance. The instruction of dragon-and-lion dance in some other universities has taken the form of short-term training given by Wushu teachers and PE teachers. Some universities also employ professional coaches responsible for intensive training.

As shown by the data analysis of the questionnaire (Table III), many college teachers have given great support to the organization of dragon-and-lion dance. Those PE teachers, especially wushu (martial art) teachers, have a deep understanding of the traditional national sports culture and sport. Besides having rich experience and achievements for field research, they have also acquired mature abilities for teaching organization and scientific teaching means, thus laying solid foundation for the instruction of dragon-and-lion dance. On the strength of their academic ability and educational ability, those college teachers are capable of improving the theoretical depth and practical skills of dragonand-lion dance. At present, a growing number of academic research achievements related to dragon-and-lion dance have been made. Some of them have also formed their own theoretical systems.

TABLE III. THE SURVEY OF THE SATISFACTION DEGREE OF DRAGON-AND-LION DANCE AMONG THE TEACHING FACULTY

\begin{tabular}{|c|c|c|c|}
\hline $\begin{array}{c}\text { Teaching } \\
\text { faculty }\end{array}$ & $\begin{array}{c}\text { Highly } \\
\text { satisfied }\end{array}$ & Satisfied & $\begin{array}{c}\text { Slightly } \\
\text { satisfied }\end{array}$ \\
\hline Percent & 70 & 20 & 10 \\
\hline
\end{tabular}

With the successful implementation of dragon-and-lion dance courses, Wuhan Sports University has already made some achievements. In order to carry forward the national tradition, many college teachers have led their dragon-and-lion dance teams to participate in various competitions, performances and public service activities. They are devoted to upholding the traditional culture and interpreting the spirit of dragon-and-lion dance in a newest and most leading manner. Besides bringing the national traditional event to the attention of more people in the society, they have also exchanged experience with other industrial experts. To be more specific, those young and energetic teachers are sent out for the study and exchange. Due to the rich teaching resources, excellent physical quality of those college students, outstanding teaching faculty and well-developed dragon-and-lion dance team, Wuhan Sports University has outperformed other ordinary universities to a certain extent. The excellent teaching faculty of the universities can have a deep understanding of the development direction of the discipline and major as well as master a lot of most advanced skills and theoretical knowledge. They can provide systematic education on dragon-and-lion dance for those students and thus lay solid foundation for setting up the course of dragon-and-lion dance in the universities. The excellent teaching faculty is also a necessary condition for developing dragon-and-lion dance in the universities.

\section{THE BASIC ANALYSIS OF THE CURRENT STATUS OF THE EXTRACURRICULAR DRAGON-AND-LION DANCE IN THE UNIVERSITIES OF WUHAN}

\section{A. The Survey of the Extracurricular Dragon-and-lion Dance} which is Not Available

As shown by the survey aimed at those students who have not participated in the extracurricular dragon-and-lion dance, 60 percent of those college students mainly utilize media and network to gain more knowledge about dragon-and-lion dance. 30 percent of those students have known more about it through the channels such as local folk custom and the performance during Lantern Festival. 96 percent of those college students have strongly supported the organization of dragon-and-lion dance which can enrich the extracurricular cultural life of those students and also reflect the emphasis of the universities on the campus culture building. Moreover, it can also make the best of the artistic creativity and cultivate the students' ability to appreciate the art. 60 percent of those college students are willing to participate in the extracurricular dragon-and-lion dance. 25 percent of those college students remain neutral. Although dragon-and-lion dance can enrich their college life and improve their physical quality, they can also find other options such as playing video game. 10 percent of those college students can not participate in dragon-and-lion dance 
because of their poor physical condition but still want to cheer for those students taking part in it. However, 5 percent of college students are opposed to it because they consider it as a waste of time. As to the form of dragon-and-lion dance, 60 percent of college students hope for the relevant course given by professional teachers so that they can study dragon-and-lion dance in a systematic manner. 30 percent of them hope to take part in dragon-and-lion dance through student associations. 10 percent of them hope to learn more about the culture of dragonand-lion dance through elective courses. As a typical example of the excellent traditional national culture of China, the education of dragon-and-lion dance on campus can not only improve the humanistic quality of college students but also contribute to the building of excellent campus culture.

\section{B. The Survey of the Extracurricular Dragon-and-lion Dance which is Available}

According to the survey aimed at those students who have participated in dragon-and-lion dance, different college students have participated in it for different reasons. 44.7 percent of them have a deep passion for the traditional sports culture and also find much interest in participating in dragonand-lion dance. They also believe that dragon-and-lion dance can reflect the national spirit as well as spread and uphold the traditional sports culture. 21 percent of them believe that dragon-and-lion dance can improve their physical quality and enrich their college life. 10 percent of them have taken part in it out of curiosity. The remaining few students have accepted it because it is required academically. Judging from the data above, the national sport of dragon-and-lion dance can appeal to those college students with its inherent cultural charm and eye-catching performance so that they are optimistic about the organization of dragon-and-lion dance on campus. The development of dragon-and-lion dance in the universities has also shown an upward tendency.

As to the study of dragon-and-lion dance in those universities offering the relevant courses, most students find it easy to study the dance. Only a few students which relatively poor physical quality can not study it with ease. In other words, the technical difficulty of dragon-and-lion dance is a factor hindering the development of dragon-and-lion dance in the universities.

\section{THE FACTORS INFLUENCING THE DEVELOPMENT OF DRAGON-AND-LION DANCE IN THE UNIVERSITIES}

\section{A. The Restricting Factor of Talent}

The organization of dragon-and-lion dance mainly relies on the emergence of a large number of talents. Compared with other places, those universities have some advantages in terms of talent. However, the survey shows that many universities have not yet assigned the professional talents, such as teacher and coach, to dragon-and-lion dance, because they began to organize it relatively late. Most of those people devoted to dragon-and-lion dance are the teachers majoring in wushu (martial art) or those people with a strong physical quality. They have some advantages compared with other majors. As shown by the survey aimed at those college students, 42 percent of them find it difficult to master the skills for dragonand-lion dance and 20 percent of them find it useless. It can be seen that greater efforts should be made to publicize dragonand-lion dance as a traditional sports cultural event because many college students still know little about it. In a word, the developemnt of dragon-and-lion dance in the universities is still faced with some challenges (See Table IV).

TABLE IV. THE FACTORS INFLUENCING THOSE STUDENTS' PARTICIPATION IN DRAGON-AND-LION DANCE

\begin{tabular}{|c|c|c|c|c|}
\hline & $\begin{array}{c}\text { Lack of } \\
\text { interest }\end{array}$ & $\begin{array}{c}\text { Lack of } \\
\text { leisure } \\
\text { time }\end{array}$ & $\begin{array}{c}\text { Afraid of } \\
\text { technical } \\
\text { difficulty }\end{array}$ & $\begin{array}{c}\text { Feel it } \\
\text { useless }\end{array}$ \\
\hline Number & 30 & 42 & 76 & 36 \\
\hline Percent & 12 & 30 & 42 & 20 \\
\hline
\end{tabular}

B. The Restricting Factor of Professional Teaching Materials and Courses

The dragon-and-lion dance in the university mainly takes the form of professional student association, sports event and specialized required course. It is easier to study the former two through the video, audio and practice. As to the last one, it involves some difficulty in preparing the teaching materials for the specialized required course. The teaching materials are the key to implementing the national and traditional culture education and improving the humanistic qualities of those college students. Teaching methods should be based on teaching courses, which means that the quality of teaching courses will directly impact the teaching quality.

Considering that dragon-and-lion dance does not have a long history on campus, the teaching materials still remain to be improved in many regards.

\section{The Restricting Factor of Campus Culture Building}

The campus culture building should lay greater emphasis on the dragon-and-lion dance as a form of national culture sport. As far as the management system is concerned, the emphasis of the school management on the sport will increase the input into dragon-and-lion dance in terms of resource and fund. The training site, facilities and external training for those teachers will be also improved. Besides, it will contribute to the campus culture building. If the campus culture buildings do not emphasize it and the school managements still adhere to the view that dragon-and-lion dance is just a waste of time and money and thus not worth investment, it will hinder the development of dragon-and-lion dance on campus.

\section{THE COUNTERMEASURES AND SUgGESTIONS FOR THE DEVELOPMENT OF DRAGON-AND-LION DANCE}

Dragon-and-lion dance is the most typical form of the excellent national traditional culture of China. The education of dragon-and-lion dance on campus can not only improve the humanistic quality of those college students but also greatly contribute to the building of excellent campus culture. Some measures below should be adopted to facilitate the development of dragon-and-lion dance.

\section{A. Utilize the Campus Culture Building to Enhance the Promotion of Dragon-and-lion Dance Culture}

The development and popularity of dragon-and-lion dance which is a folk sports event on campus should receive the recognition and great support from the school management. 
With the aid of campus culture building, the cultural promotion of dragon-and-lion dance will be also enhanced. The organization of dragon-and-lion dance in the universities can not only combine the traditional national sport with modern competitive sport organically but also enrich the essence, artistic color and content of the sport. Those college students will be able to better appreciate dragon-and-lion dance and make the innovation to keep pace with the times. Therefore, the organization of dragon-and-lion dance on campus can reflect the sports spirit in the modern world and thus win the recognition from the school management.

\section{B. Enhance the Building of Teaching Faculty and Introduce}

Professional Knowledge and Technical Talents

Those teachers majoring in sport can receive the systematic education on dragon-and-lion dance. If possible, they can study and absorb the experience outside or receive the instruction of the professional teachers specializing in dragon-and-lion dance. In a word, an excellent teaching faculty is the precondition for developing dragon-and-lion dance on campus.

C. The College Students' ability and Teamwork Spirit Should be Improved

D. The Building of Teaching Materials and Courses Relevant to Dragon-and-lion Dance in the Sports Universities Should be Improved so that those Students can have a Deeper Understanding of the Dragon-and-lion Dance Culture

\section{CONCLUSION}

With the release of national policies aimed to encourage those universities to bring more national sports events to the campus and improve the overall quality of college students, it has provided a good opportunity for the excellent national sports event to be included in the physical education in the universities. As an important part of national traditional sport in China, dragon-and-lion dance has comprehended the profound cultural essence. It is valuable for those universities to organize dragon-and-lion dance in many regards. The value of dragon-and-lion dance lies in enriching the leisure cultural life of college students, improving the atmosphere of campus culture as well as playing an important role in building a harmonious campus and society.

\section{REFERENCES}

[1] Chen Shiqiang. The Feasibility Research of Organizing Dragon-and-lion Dance in the Universities of Guangxi. 2009.30. Volume 91 - 92

[2] Gao Liang. The Feasibility Research of Dragon-and-lion Dance in the Universities of China. 2012. Volume 33. 4.113

[3] He Jin and Liu Yongfeng. The Research of the Current Status Analysis and Development Countermeasures for Dragon-and-lion Dance in the Universities of Jiangsu. 2008. Volume 24. 5.138

[4] Duan Quanwei and Lu Shaojun. The Current Status of the Course of Dragon-and-lion Dance in the Universities. 2012. Volume 35. 5.85 